5) J. Koryta and P. Vanýsek, in "Advances in Electrochemistry and Electrochemical Engineering," ed. by H. Gerischer and C.W. Tobias, John Wiley \& Sons, New York, Vol.12, p.113 (1981).

6) V.E. Kazarinov, ed., "The interface Structure and Electrochemical Processes at the Boundary Between Two Immiscible Liquids," Springrer-Verlag, Berlin (1987).

7) H. H. Girault and D.J. Schiffrin, in "Electroanalytical Chemistry," ed. by A.J. Bard, Marcel Dekker, New York, Vol.15, Chapter 1 (1989).

8) M. Senda, T. Kakiuchi and T. Osakai, Electrochim. Acta, 36, 253 (1991).

9）木原壯林，松井正和，裴面，30，367（1992）.

10) H. H. Girault, in "Modern Aspects of Electrochemistry," ed. by R.E. White, B.E. Conway and J.O. Bockris, Plenum, New York, Vol.25, p.1 (1993).

11) Z. Samec and T. Kakiuchi, in "Advances in Electrochemistry and Electrochemical Science," ed. by $\mathrm{H}$. Gerischer and C.W. Tobias, VCH, Weinheim, Vol.4 (1995)

12) G.M. Torrie and J.P. Valleau, J. Electroanal. Chem., 206, 69 (1986).

13) Z. Samec, Chem. Rev., 88, 617 (1988).

14) I. Benjamin, J. Chem. Phys., 97, 1432 (1992).

15) I. Benjamin, Science, 261, 1558 (1993).
16) J.C. Conboy, J.L. Daschbach and G.L. Richmond, J. Phys. Chem., 98, 9688 (1994).

17) T. Kakiuchi, J. Noguchi and M. Senda, J. Electroanal. Chem., 336, 137-152 (1992).

18) T. Kakiuchi, J. Noguchi, M. Kotani and M. Senda, J. Electroanal. Chem., 296, 517 (1990).

19) T. Kakiuchi, Y. Takasu and M. Senda, Anal. Chem., 64, 3096-§100 (1992).

20) K. Kakiuchi and Y. Takasu, Anal. Chem., 66, 1853 (1994).

21) K. Kakiuchi and $Y$. Takasu, in preparation.

22) H.H.J. Girault and D.J. Schiffrin, J. Electroanal. Chem., 195, 213 (1985).

23) Y.Y. Gurevich and Y.I. Kharkats, J. Electroanal. Chem., 200, 3 (19186).

24) T. Kakiuchi, J. Electroanal. Chem, 322, 55 (1992).

25) I. Benjamin, J. Chem. Phys., 96, 577 (1992).

26) Y. Cheng and D.J. Schiffrin, J. Chem. Soc., Faraday, 89, 199 (1993).

27) Y.I. Kharkats, Elektrokhimiya, 26, 1154 (1990).

28) R.A. Marcus, J. Phys. Chem., 94, 1050 (1990).

29) R.A. Marcus, J. Phys. Chem., 94, 4152 (1990).

30) R.A. Marcus, J. Phys. Chem., 95, 2010 (1991)

31) I. Benjamin, J. F'hys. Chem., 95, 6675 (1991).

32) I. Benjamin, Chem. Phys., 180, 287 (1994).

\title{
? 液液界面の電気化学之溶媒抽出
}

\section{木原壯林}

水 (W) とそれと混じり合わない有機溶媒（O）の間 でのイオンの分配は，イオンの分離・濃縮に活用される のみならず，生体膜の疎水部を○と見立てれば，生体 内でのイオンの取り込みの理解にも有用な知見を与える.

イオン $\left(\mathrm{i}^{z} ; \mathrm{z}\right.$ は電荷) の $\mathrm{W} ・ \mathrm{O}$ 間分配は雨相中での $\mathrm{i}^{2}$ の化学ポテンシャル $\left(\mu_{\mathrm{i}}\right)$ の差に依存する. 従って, $\mathrm{W} ・ \mathrm{O}$ 間に外部回路によってエネルギー差（電位差）を 印加する電気化学的手法あるいは対イオンを添加する溶 液化学的手法によって $\mu_{\mathrm{i}}$ の差を変化させれば，分配を 変えることができ， $\mathrm{i}^{\mathrm{z}}$ を W/O界面を横切って移動させ ることができる，前者が液液界面電解法であり，後者が イオン対抽出法である. 雨者は, 電子を利用するか詨イ オンを利用するかの違いはあっても，イオンの界面移動 を実現するという観点からは共通している.

本稿では，近年長足の進歩を遂げた電気化学測定法，

京都工芸織維大学工学部物質工学科( 崎御所海道町)
液液界面イホン移動ボルタンメトリー（VITIES）によっ て蓄積された界面イオン移動に関する知見を基に，イオ ンの抽出反応を電気化学の立場加論ずることにする。

なお，VITIESは，2液の界面での単イオンの移動反 応を, 界面を横切る電流（イオン移動量に相当）上界 面電位差（イオン移動自由エネルギー $\triangle G_{\mathrm{tr}}$ に相当）の 関係曲線（ボルタモグラム）として測定する手法である。 本稿と関連して特筆すべき VITIES の特長は, 電流の 大きさによって目的イオンの界面移動と不純物イオンの それとを区別できる点であり，この特長の故に，同法で は電位差法や電導度法などの他の電気化学測定法に比べ て格段に正確な $\triangle G_{\mathrm{tr}}$ を求めることができる，さらに， VITIES では中性配位子あるいは界面活性剤によって促 進されたイオン移動，イオン移動速度などに関する情報 あ得られる。

VITIES 測定法, ボルタモグラム式の誘導, 促進イオ ン移動反応，界面イオン移動反応の速度論などは多数の 
総説（例えば，文献 1）～5）捛よでその引用文献）に記 載されているのでここでは割愛する。

\section{1 イオンおよび溶媒の特性と W/O 界面イオン移動}

イオン $\mathrm{i}^{2}$ の W/O 界面移動が可逆である場合（多くの W/O 界面イオン移動は可逆), VITIES で求めたボル夕 モグラム半波電位 $\Delta V_{1 / 2}$ は, 限界拡散電流および搪張 Debye-Hükel 式などから推定した㹡散定数および活量 係数で補正することによって, 標準 W/O 界面ガルバ二 電位差 $\triangle \phi^{0}$ に換算でき，さらに，次式によって標準 W $/ O$ 界面イオン移動自由エネルギー- $\triangle G_{\text {tr }}{ }^{0}$ に関係付けら れる ${ }^{2,4,5)}$.

$$
\triangle \phi^{0}=-\triangle G_{\mathrm{tr}}^{0} / z F
$$

$\triangle V_{1 / 2}$ の測定值およびそれを㫷にして求めた各種の i単イオンの $\triangle G_{\mathrm{tr}}{ }^{0}$ は総説 $2,4,5$ などにまとめてある. 以下，これらの値を参照しながら議論する。

$\triangle G_{\text {ur }}{ }^{0}$ は，W，O中の $\mathrm{i}^{2}$ に上って生じる標準化学ポ テンシャル $\mu_{\mathrm{i}, \mathrm{w}}{ }^{0} ， \mu_{\mathrm{i}, 0^{0}}$ の差ですり，イオン対生成や 特殊な錯生成が無視できる場合には，雨相での $i^{z} の$ 標 準溶媒和自由エネルギー $\triangle G_{\mathrm{s}}{ }^{0}(\mathrm{~W}), \Delta G_{\mathrm{s}}{ }^{0}(\mathrm{O})$ の差で ある.

$$
\triangle G_{\mathrm{tr}}{ }^{0}=\mu_{\mathrm{i}, 0}{ }^{0}-\mu_{\mathrm{i}, \mathrm{w}}{ }^{0}=\Delta G_{\mathrm{s}}{ }^{0}(\mathrm{O})-\triangle G_{\mathrm{s}}{ }^{0}(\mathrm{~W})
$$

また， $\triangle G_{\mathrm{s}}{ }^{0}$ は，遠距離で㗢く静電相互作用 $\triangle G_{\mathrm{s}}{ }^{0}(\mathrm{el})$, 近距離で働く静電相互作用 $\triangle G_{\mathrm{s}}{ }^{0}(\mathrm{sr})$, 非静電的相互作 用 $\triangle G_{\mathrm{s}}{ }^{0}$ (ne) で特街付けられる ( $\alpha, \beta, \gamma$ は係数).

$$
\triangle G_{\mathrm{s}}{ }^{0}=\alpha \triangle G_{\mathrm{s}}{ }^{0}(\mathrm{el})+\beta \triangle G_{\mathrm{s}}{ }^{1}{ }(\mathrm{sr})+\gamma \triangle G_{\mathrm{s}}{ }^{0}(\mathrm{ne})
$$

$\triangle G_{\mathrm{s}}{ }^{0}(\mathrm{el})$ は溶媒の形成する場の刘果とも考元られ， Born 式あるいはその修正式で景されるように， z，

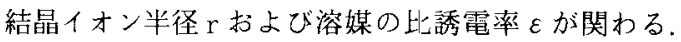
$\triangle G_{\mathrm{s}}{ }^{0}(\mathrm{sr})$ は， $\mathrm{i}^{2}$ 之溶媒分子上の錯生成エネルギーと 李考えられ，z，r， i ${ }^{z}$ 電子軌道，溶媒分子の極性なよ゙ が関わる. $\triangle G_{\mathrm{s}}{ }^{0}(\mathrm{el})$ と $\triangle G_{\mathrm{s}}{ }^{0}(\mathrm{~s} \mathrm{r})$ が大きいほど $\mathrm{i}^{2}$ 注 溶媒中で安定である． $\triangle G_{\mathrm{s}}{ }^{0}(\mathrm{ne})$ は，溶媒分子間の結 合を切断して，溶媒中に $\mathrm{i}^{2}$ を入机るための空孔を造る エネルギーであり， $\mathrm{i}^{\mathrm{z}}$ の大きさ之溶媒分子間の結合（構 造性）の強さが関与する。 $\triangle G_{\mathrm{s}}{ }^{0}(\mathrm{ne})$ は $\mathrm{i}^{\mathrm{z}}$ を溶媒から 排除する効果として働き，大きいほよ゙ $\mathrm{i}^{2}$ は溶媒中で不 安定である。

アルカリ金属イオン，八ロゲン化物イオンや $\mathrm{ClO}_{4}^{-}$, $\mathrm{IO}_{4}^{-}, \mathrm{BrO}_{3}^{-}, \mathrm{NO}_{3}{ }^{-}, \mathrm{BF}_{4}^{-}$などのあまり大きくない 1 価多原子アニオンの $\triangle G_{\mathrm{s}}{ }^{0}$ は主として $\triangle G_{\mathrm{s}}{ }^{0}(\mathrm{el})$ によっ て決定され， $\triangle G_{s}{ }^{0}(\mathrm{sr}), \triangle G_{\mathrm{s}}{ }^{0}$ (ne)の寄与は小さい. 従って, W および 0 の中での $\triangle G_{\mathrm{s}}{ }^{0}$ の差である $\triangle G_{\mathrm{tr}}{ }^{0}$ は $\mathrm{z} / \mathrm{r}$ と直線関係にある ${ }^{6)}$ (Born 式参照)。 $\mathrm{d}$ や f 電子 を持つ遷移金属イオンの溶媒和では， $\triangle G_{\mathrm{s}}{ }^{0}(\mathrm{e} \mathrm{l})$ に加 えて $\triangle G_{\mathrm{s}}{ }^{0}(\mathrm{sr})$ が大きく寄与する。，一方，かさ高いイ
オンの溶媒和では $\triangle G_{\mathrm{s}}{ }^{0}(\mathrm{ne})$ を無視できない，例えば, $\mathrm{R}$ が $\mathrm{CH}_{3}\left(\mathrm{CH}_{2}\right)_{\mathrm{n}} \mathrm{CH}_{2}$ である $\mathrm{RCOO}^{-}$や $\mathrm{RSO}_{3}{ }^{-}$の W からニトロベンゼン (NB) 拈よびクロロホルム (CF) への $\triangle G_{\mathrm{tr}}{ }^{0}$ は $\mathrm{n}$ が 1 増加する每に約 3.7 および 3.4 $\mathrm{kJmol}^{-1}$ 減少する ${ }^{7)}$. これらのイオンの電荷は $\mathrm{CH}_{2}$ $\mathrm{COO} \mathrm{C} \mathrm{CH}_{2} \mathrm{SO}_{3}$ 部分に偏在し, $\mathrm{CH}_{3}\left(\mathrm{CH}_{2}\right)_{\mathrm{n}}$ 部分は 中性である，中性部分の溶媒和は $\triangle G_{\mathrm{s}}{ }^{0}($ ne $)$ にょって 支配され，水素結合性で構造性の高い $\mathrm{W}$ 中の方が $\mathrm{O}$ 中 より大きき，中性部分の体積 $\left(\mathrm{CH}_{2}\right.$ の数 $\left.\mathrm{n}\right)$ に比例す るので上記の結果となる。な斿，同じ R を持つ RCOO 之 $\mathrm{RSO}_{3}{ }^{-}$の $\triangle G_{\mathrm{tr}}{ }^{0}$ の差はO が $\mathrm{NB}, \mathrm{CF}$ のとき平均 $6.5,6.8 \mathrm{kJmol}^{-1}$ であるが，これは電荷部分の $\triangle G_{\mathrm{s}}{ }^{0}$ （el）の差に起因する， R が芳香環である $\mathrm{RCOO}^{-}$や $\mathrm{RSO}_{3}{ }^{-}$- $\triangle G_{\mathrm{tr}}{ }^{0}$ は $\mathrm{R}$ の体積加ら予测される屯のより小 さい，電荷が共鳴によって芳香環にも分布し， $\triangle G_{s}{ }^{0}$ （el）が変わるためである.

以上のように, $\triangle G_{\mathrm{tr}}{ }^{n} に は \mathrm{i}^{2}$ の電荷, 外殼電子軌道 の種類，サイズ， $\mathrm{i}^{2}$ 内での電荷の分布が深く係わる.

\section{2 単イオンのW/O界面移動とイオン対抽出平衡}

イオン対抽出に関する研究の大部分では，抽出反応の 過程を Fig. 1 (a) のように, (1) 先ず, W 中の目的イ オン $\mathrm{M} か ゙ \mathrm{~W}$ 中で対イオン $\mathrm{X}$ とイオン対を生成する， (2) 次いで，中性のイオン対が ○に移動する，(3)移動し たイオン対は $\mathrm{O}$ 中である程度解離するとしている。し

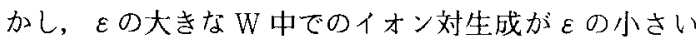
○中でのそれに勝るという考えは電解質溶液論の常識之 矛盾し，この機構には疑問が残る。また，この機構で抽 出平衡定数 $\mathrm{K}_{\mathrm{ex}}$ 老 $\mathrm{M}, \mathrm{X}$ の溶液化学的性質上関係付け て説明することは難しい，一方，少数ではあるが，

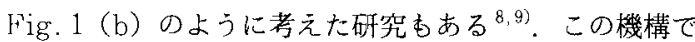
は，(1) M およびXは単イオンとしてそれぞれの $\triangle G_{\mathrm{tr}}{ }^{0}$ にしたがって電気的中性則を満足しながらWから○に 移動し，(2) $\varepsilon$ のさいO中で一部はイオン対を生成す るとしている．著者らもこの機構によれば実駼結果を矛 盾なく説明できると考えている，以下では，(b) の機構 を採用し，1 価イオンを例として $\mathrm{K}_{\mathrm{ex}}$ を考察する ${ }^{5,10)}$. な㧍，簡単のために活量係数は全て 1 とする。

いま， $\mathrm{M}^{+}$を含む $\mathrm{W}$ に $\mathrm{X}^{-}$を加えて $\mathrm{W}$ と等容の $\mathrm{O}$ と

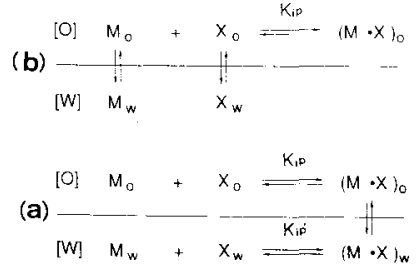

Fig. 1 Probable processes proposed for ionpair exiraction. 
振り混ぜ， $\mathrm{M}^{+} を \mathrm{O}$ に抽出するとする. 抽出平衡は式 (4) で表される.

$\mathrm{M}^{+}{ }_{\mathrm{W}}+\mathrm{X}^{-{ }_{\mathrm{W}}} \rightleftarrows \mathrm{M}_{\mathrm{T}, 0}+\mathrm{X}_{\mathrm{T}, 0}$

$\mathrm{M}_{\mathrm{T}, \mathrm{O}}, \mathrm{X}_{\mathrm{T}, \mathrm{O}}$ は $\mathrm{O}$ 中心全 $\mathrm{M}^{+}$関連化学種, 全 $\mathrm{X}^{-}$関連化 学種を示す。ここでは, 抽出された $\mathrm{M}^{+}, \mathrm{X}^{-}$が $\mathrm{O}$ 中で 次式のようにイオン対 $\mathrm{M}^{+} \cdot \mathrm{X}^{-}$を生成する（生成定数 $K_{i p}$ ) と考えている.

$\mathrm{M}^{+}{ }_{0}+\mathrm{X}^{-}{ }_{0} \rightleftarrows \mathrm{M}^{+} \cdot \mathrm{X}^{-}{ }_{0}$

以下, 平衡後の $\mathrm{M}^{+}$および $\mathrm{X}^{-}$の $\mathrm{W}$ 中濃度を $\mathrm{C}_{\mathrm{M}, \mathrm{W}}$ および $\mathrm{C}_{\mathrm{X}, \mathrm{W}}, \mathrm{O}$ 中濃度を $\mathrm{C}_{M, O}$ および $\mathrm{C}_{\mathrm{X}, \mathrm{O}}$, O 中の $\mathrm{M}^{+} \cdot \mathrm{X}^{-}$濃度を $\mathrm{C}_{\mathrm{ip}, \mathrm{O}}, \mathrm{O}$ 中の $\mathrm{M}^{+} お よ ひ ゙ \mathrm{X}-$ 関連化学 種の全濃度を $\mathrm{C}_{\mathrm{TM}, \mathrm{O}}$ 抢よび $\mathrm{C}_{\mathrm{TX}, \mathrm{O}}$ として議論を進める。 ただし，O中での電気的中性則によって， $\mathrm{C}_{\mathrm{M}, \mathrm{O}}$ 上 $\mathrm{C}_{\mathrm{X}, \mathrm{O}}$ は等しく $\left(\mathrm{C}_{\mathrm{i}, \mathrm{O}}\right.$ と置く), 従って, $\mathrm{C}_{\mathrm{TM}, \mathrm{O}}<\mathrm{C}_{\mathrm{TX}, \mathrm{O}}$ も等 しい ( $\mathrm{C}_{\mathrm{T}, \mathrm{O}}$ と置く).

$\mathrm{C}_{\mathrm{i}, 0}=\mathrm{C}_{\mathrm{M}, 0}=\mathrm{C}_{\mathrm{X}, \mathrm{D}}$

$\mathrm{C}_{\mathrm{T}, 0}=\mathrm{C}_{\mathrm{TM}, 0}=\mathrm{C}_{\mathrm{TX}, 0}=\mathrm{C}_{\mathrm{i}, 0}+\mathrm{C}_{\mathrm{ip}, 0}$

$\mathrm{K}_{\mathrm{ex}}$ は次式で与えられる。

$\mathrm{K}_{\mathrm{ex}}=\mathrm{C}_{\mathrm{TM}, 0} \mathrm{C}_{\mathrm{TX}, 0} / \mathrm{C}_{\mathrm{M}, \mathrm{w}} \mathrm{C}_{\mathrm{X}, \mathrm{W}}=\mathrm{C}_{\mathrm{T}, 0}{ }^{2} / \mathrm{C}_{\mathrm{M}, \mathrm{W}} \mathrm{C}_{\mathrm{X}, \mathrm{W}}$

さらに, $\mathrm{M}^{+}$と $\mathrm{X}$ の $\mathrm{W}$ ○間での分配比を $\mathrm{R}_{\mathrm{M}}, \mathrm{R}_{\mathrm{X}}$ とすると，

$$
\begin{gathered}
\mathrm{R}_{\mathrm{M}}=\mathrm{C}_{\mathrm{TM}, 0} / \mathrm{C}_{\mathrm{M}, \mathrm{W}}=\mathrm{C}_{\mathrm{T}, 0} / \mathrm{C}_{\mathrm{M}, \mathrm{W}} \\
\mathrm{R}_{\mathrm{X}}=\mathrm{C}_{\mathrm{TX}, 0} / \mathrm{C}_{\mathrm{X}, \mathrm{W}}=\mathrm{C}_{\mathrm{T}, \mathrm{l}} / \mathrm{C}_{\mathrm{X}, \mathrm{W}} \\
\text { であるから, 次の関係を得る. }
\end{gathered}
$$

$$
\mathrm{K}_{\mathrm{ex}}=\mathrm{R}_{\mathrm{M}} \mathrm{R}_{\mathrm{x}}
$$

一方, $\mathrm{O}$ 中に抽出された $\mathrm{M}^{+}, \mathrm{X}^{-}$のイオン対生成定 数 $\mathrm{K}_{\mathrm{ip}}$ は式 (12) で表せるふら，式 (7) を用いて式 (13) を得る。

$$
\begin{aligned}
& \mathrm{K}_{\mathrm{ip}}=\mathrm{C}_{\mathrm{ip}, 0} / \mathrm{C}_{\mathrm{i}, 0}{ }^{2} \\
& \mathrm{C}_{\mathrm{i}, 0}=\left\{-1+\left(1+4 \mathrm{~K}_{\mathrm{ip}} \mathrm{C}_{\mathrm{T}, 0}\right)^{1 / 2}\right\} / 2 \mathrm{~K}_{\mathrm{ip}}
\end{aligned}
$$

ここで, 抽出前の $\mathrm{W}$ 中の $\mathrm{M}^{+}, \mathrm{X}^{-}$の濃度が $\mathrm{C}_{\mathrm{M}}{ }^{0}$ : $\mathrm{C}_{\mathrm{X}}{ }^{0}$ であり, $\mathrm{C}_{\mathrm{X}}{ }^{0}$ が $\mathrm{C}_{\mathrm{M}}{ }^{0}$ の $\alpha$ 倍であったとすると,

$$
\begin{aligned}
& \mathrm{C}_{\mathrm{M}}{ }^{0}=\mathrm{C}_{\mathrm{M}, \mathrm{W}}+\mathrm{C}_{\mathrm{T}, 0} \\
& \mathrm{C}_{\mathrm{X}}{ }^{0}=\alpha \mathrm{C}_{\mathrm{M}}{ }^{0}=\mathrm{C}_{\mathrm{X}, \mathrm{W}}+\mathrm{C}_{\mathrm{T}, 0}
\end{aligned}
$$

が成立ち，式 (9)，(10)，（13）加ら次の諸関係を得る.

$$
\begin{aligned}
& \mathrm{C}_{\mathrm{T}, 0}=\mathrm{R}_{\mathrm{M}} \mathrm{C}_{\mathrm{M}}{ }^{0} /\left(1+\mathrm{R}_{\mathrm{M}}\right) \\
& \mathrm{C}_{\mathrm{i}, 0}=\left[-1+\left\{\left(1+\mathrm{R}_{\mathrm{M}}+4 \mathrm{~K}_{\mathrm{ip}} \mathrm{R}_{\mathrm{M}} \mathrm{C}_{\mathrm{M}}{ }^{0}\right) /\right.\right. \\
& \left.\left.\quad\left(1+\mathrm{R}_{\mathrm{M}}\right)\right\}^{1 / 2}\right] / 2 \mathrm{~K}_{\mathrm{ip}} \\
& \mathrm{C}_{\mathrm{M}, \mathrm{W}}=\mathrm{C}_{\mathrm{M}}{ }^{0} /\left(1+\mathrm{R}_{\mathrm{M}}\right) \\
& \mathrm{C}_{\mathrm{X}, \mathrm{W}}=\mathrm{C}_{\mathrm{M}}{ }^{0}\left\{(\alpha-1) \mathrm{R}_{\mathrm{M}}+\alpha\right\} /\left(1+\mathrm{R}_{\mathrm{M}}\right)
\end{aligned}
$$

また, 抽出平衡定数 $\mathrm{K}_{\mathrm{ex}}$ は, 式 (11)，(16) （19）より,

$$
K_{\text {ex }}=R_{M} R_{X}=\left[R_{M}{ }^{2} /\left\{(\alpha-1) R_{M}+\alpha\right\}\right]
$$

$$
\text { と書き表せる。 }
$$

一方， $\mathrm{M}^{+}$および $\mathrm{X}^{-}$の垎々が分配することによって 発生するW/O界面電位差 $\triangle \phi_{\mathrm{M}}$ および $\triangle \phi_{\mathrm{X}}$ (分配電位 とも呼ばれる）は，画相のイオンの濃度に依存するので，

$$
\triangle \phi_{\mathrm{M}}=\Delta \phi^{0}{ }_{\mathrm{M}}-(\mathrm{RT} / \mathrm{F}) \ln \left(\mathrm{C}_{\mathrm{M}, 0} / \mathrm{C}_{\mathrm{M}, \mathrm{W}}\right)
$$

$$
\triangle \phi_{\mathrm{x}}=\Delta \phi^{0}{ }_{\mathrm{X}}+(\mathrm{RT} / \mathrm{F}) \ln \left(\mathrm{C}_{\mathrm{X}, 0} / \mathrm{C}_{\mathrm{X}, \mathrm{w}}\right)
$$

と表せ，イオン対生成を伴う場合には，式 (17)～(19) および (21)，(22）から次のようになる.

$$
\begin{aligned}
\Delta \phi_{\mathrm{M}}= & \Delta \phi^{0}{ }_{\mathrm{M}}-(\mathrm{K} T / \mathrm{F}) \ln \left[\left(1+\mathrm{R}_{\mathrm{M}}\right)\right. \\
& {\left[-1+\left\{\left(1+\mathrm{R}_{\mathrm{M}}+4 \mathrm{~K}_{\mathrm{ip}} \mathrm{R}_{\mathrm{M}} \mathrm{C}_{\mathrm{M}}{ }^{0}\right)\right.\right.} \\
& \left.\left.\left./\left(1+\mathrm{R}_{\mathrm{M}}\right)\right\}^{1 / 2}\right] / 2 \mathrm{C}_{\mathrm{M}}{ }^{\mathrm{K}_{\mathrm{ip}}}\right] \\
\triangle \phi_{\mathrm{X}}= & \Delta \phi^{0}{ }_{\mathrm{X}}+(\mathrm{RT} / \mathrm{F}) \ln \left[\left(1+\mathrm{R}_{\mathrm{M}}\right)[-1+\right. \\
& \left.\left\{\left(1+\mathrm{R}_{\mathrm{M}}+4 \mathrm{~K}_{\mathrm{ip}} \mathrm{R}_{\mathrm{M}} \mathrm{C}_{\mathrm{M}}{ }^{0}\right) /\left(1+\mathrm{R}_{\mathrm{M}}\right)\right\}^{1 / 2}\right] \\
& \left./ 2 \mathrm{C}_{\mathrm{M}}{ }^{1 / 2} \mathrm{~K}_{\mathrm{ip}}\left\{(\alpha-1) \mathrm{R}_{\mathrm{M}}+\alpha\right\}\right]
\end{aligned}
$$

抽出平衡は目的界面での $\triangle \phi_{\mathrm{M}}\left\llcorner\triangle \phi_{\mathrm{X}}\right.$ が等しくなっ たときに達成されるから，式 (23)，（24）より，

$\left(\mathrm{F} / \mathrm{R}^{\mathrm{T}} \mathrm{)}\right)\left(\triangle \phi^{0}{ }_{\mathrm{M}}-\triangle \phi^{0} \mathrm{x}\right)$

$$
\begin{aligned}
& =\ln \left[( 1 + \mathrm { R } _ { \mathrm { M } } ) ^ { 2 } \left[-1+\left\{\left(1+\mathrm{R}_{\mathrm{M}}+4 \mathrm{~K}_{\mathrm{ip}} \mathrm{R}_{\mathrm{M}} \mathrm{C}_{\mathrm{M}}{ }^{0}\right)\right.\right.\right. \\
& \left.\left.\left./\left(1+\mathrm{R}_{\mathrm{M}}\right)\right\}^{1 / 2}\right]^{2} / 4\left(\mathrm{C}_{\mathrm{M}}{ }^{0} \mathrm{~K}_{\mathrm{ip}}\right)^{2}\left\{(\alpha-1) \mathrm{R}_{\mathrm{M}}+\alpha\right\}\right]
\end{aligned}
$$

(25)

を得る. 式 (25) は, $\mathrm{C}_{\mathrm{M}}{ }^{0}$ が希薄で $\mathrm{K}_{\mathrm{i} p}$ が小さくイオン 対生成を無視できる場合 $\left(\mathrm{C}_{\mathrm{M}}{ }^{0} \mathrm{~K}_{\mathrm{ip}} \ll 1\right.$ の場合）には式 (26), さらに $\alpha=1$ の場合には式 (27) のように簡単な 関係となる。

$$
\begin{aligned}
& (\mathrm{F} / \mathrm{RT})\left(\Delta \phi^{0}{ }_{\mathrm{M}}-\Delta \phi^{0}{ }_{\mathrm{x}}\right) \\
& \quad=\ln \left[\mathrm{R}_{\mathrm{M}}{ }^{2} /\left\{(a-1) \mathrm{R}_{\mathrm{M}}+\alpha\right\}\right]
\end{aligned}
$$

$(\mathrm{F} / \mathrm{RT})\left(\triangle \phi^{0}{ }_{\mathrm{M}}-\Delta \phi^{0}{ }_{\mathrm{X}}\right)=\ln \mathrm{R}_{\mathrm{M}}{ }^{2}$

また， $\mathrm{C}_{\mathrm{M}}{ }^{0}$ が濃得で $\mathrm{F}_{\mathrm{M}}$ 抢よび $\mathrm{K}_{\mathrm{ip}}$ が大きく $\mathrm{O}$ 中でイ オン刘生成が優先する場合（例えば $\mathrm{C}_{\mathrm{M}}{ }^{0} \mathrm{~K}_{\mathrm{ip}}>10^{3}$, $\mathrm{R}_{\mathrm{M}} \gg 1$ の場合）には次式のようになる。

$(\mathrm{F} / \mathrm{RT})\left(\triangle \phi^{0}{ }_{\mathrm{M}}-\Delta \phi^{0}{ }_{\mathrm{X}}\right)$

$$
=\ln \left[\mathrm{R}_{\mathrm{M}}{ }^{2} / \mathrm{C}_{\mathrm{M}^{0}} \mathrm{~K}_{\mathrm{ip}}\left\{(\alpha-1) \mathrm{R}_{\mathrm{M}}+\alpha\right\}\right]
$$

次に，O中に抽出された $\mathrm{M}^{+}$が中性配位子 $\mathrm{Y}$ と錯体 $\mathrm{MY}^{+}$を生成し， $\mathrm{M}^{+}$の $\mathrm{W} / \mathrm{O}$ 界面移動が促進される場合 のイオン対抽出平衡（協同イオン対抽出平衡）を考え る. 以下, $\mathrm{C}_{\mathrm{M}, \mathrm{w}}, \mathrm{C}_{\mathrm{X}, \mathrm{W}}, \mathrm{C}_{\mathrm{M}, \mathrm{O}}, \mathrm{C}_{\mathrm{X}, \mathrm{O}}, \mathrm{C}_{\mathrm{TM}, \mathrm{O}}, \mathrm{C}_{\mathrm{TX}, \mathrm{O}}$, $\mathrm{C}_{\mathrm{T}, \mathrm{O}}, \mathrm{C}_{\mathrm{M}}{ }^{0}, \mathrm{C}_{\mathrm{X}}{ }^{0}\left(=\alpha \mathrm{C}_{\mathrm{M}}{ }^{0}\right)$ を先之同様なもの, $\mathrm{C}_{\mathrm{Y}, 0}$, $\mathrm{C}_{\mathrm{MY}, \mathrm{O}} \mathrm{O}$ 中の $\mathrm{Y}, \mathrm{MY}^{+}$濃度とする.ただし, $\mathrm{C}_{\mathrm{TM}, \mathrm{O}}$, $\mathrm{C}_{\mathrm{T}, \mathrm{O}}$ は,

$$
\begin{aligned}
& \mathrm{C}_{\mathrm{TM}, 0}=\mathrm{C}_{\mathrm{M}, 0}+\mathrm{C}_{\mathrm{MY}, 0} \\
& \mathrm{C}_{\mathrm{T}, 0}=\mathrm{C}_{\mathrm{TM}, 0}=\mathrm{C}_{\mathrm{X}, 0} \quad \text { (電気的中性則) }
\end{aligned}
$$

と定義する.イオン対生成は無視する.

$\mathrm{O}$ 中での錯生成反応老,

$$
\mathrm{M}^{+}{ }_{0}+\mathrm{Y}_{0} \rightleftarrows \mathrm{MY}^{+}{ }_{0}
$$

とすれば，錯生成定数 $K_{\text {st }}$ は次式で表される。

$$
\mathrm{K}_{\mathrm{st}}=\mathrm{C}_{\mathrm{MY}, 0} / \mathrm{C}_{\mathrm{M}, 0} \mathrm{C}_{\mathrm{Y}, 0}
$$

また，式 (9)〜 (11)，(14) （16)，(18)，(19）の諸関係 および次の関係が成り立つ。

$$
\begin{aligned}
\mathrm{C}_{\mathrm{M}, 0} & =\mathrm{C}_{\mathrm{TM}, 0} /\left(1+\mathrm{K}_{\mathrm{st}} \mathrm{C}_{\mathrm{Y}, 0}\right) \\
& =\mathrm{R}_{\mathrm{M}} \mathrm{C}_{\mathrm{M}}{ }^{0} /\left\{\left(1 .+\mathrm{R}_{\mathrm{M}}\right)\left(1+\mathrm{K}_{\mathrm{st}} \mathrm{C}_{\mathrm{Y}, 0}\right)\right\}
\end{aligned}
$$

ここで，イオン対抽出平衡を次式で定義すると,

$\mathrm{M}^{+}{ }_{\mathrm{W}}+\mathrm{X}_{\mathrm{w}}{ }_{\mathrm{W}} \rightleftarrows \mathrm{M}_{\mathrm{T}, 0}+\mathrm{X}^{-} \mathrm{O}$

抽出平衡定数 $\mathrm{K}_{\mathrm{ex}}$ は, 式 (8), （20）と同様な型となる. 
一方, 錯生成を伴う場合の W/O 界面電位差 $\triangle \phi_{M}$ お よび $\triangle \phi_{\mathrm{X}}$ は次のように表され（式 (21)，(22）参照), $\triangle \phi_{\mathrm{M}}=\Delta \phi^{0}{ }_{\mathrm{M}}-(\mathrm{RT} / \mathrm{F}) \ln \left\{\mathrm{R}_{\mathrm{M}} /\left(1+\mathrm{K}_{\mathrm{st}} \mathrm{C}_{\mathrm{Y}, 0}\right)\right\}$

$\triangle \phi_{\mathrm{X}}=\Delta \phi^{0}{ }_{\mathrm{X}}+(\mathrm{RT} / \mathrm{F}) \ln \left[\mathrm{F}_{\mathrm{v}} \mathrm{M} /\left((\alpha-1) \mathrm{R}_{\mathrm{M}}+\alpha\right\}\right]$

抽出平衡では $\triangle \phi_{M}=\triangle \phi_{X}$ よなるので, 式 (37)を得る.

$(\mathrm{F} / \mathrm{RT})\left(\triangle \phi^{0}{ }_{\mathrm{M}}-\triangle \phi^{0}{ }_{\mathrm{X}}\right)$

$$
=\ln \left[\mathrm{R}_{\mathrm{M}}{ }^{2} /\left[\left(1+\mathrm{K}_{\mathrm{st}} \mathrm{C}_{\mathrm{Y}, 0}\right)\left\{(\alpha-1) \mathrm{R}_{\mathrm{M}}+\alpha\right\}\right]\right]
$$

式 (37) は, $\mathrm{K}_{\mathrm{st}}$ が小さく $\mathrm{C}_{Y, 0}$ が希薄で, 錯生成を無 視できる場合 $\left(\mathrm{K}_{\mathrm{st}} \mathrm{C}_{\mathrm{Y}, 0} \ll 1\right.$ の場合) には式 (26) 上， さらに $\alpha=1$ の場合には式 (27) と一致する。，一方， $\mathrm{K}_{\mathrm{st}}$ が大きく, $\mathrm{C}_{\mathrm{Y}, 0}$ が濃厚であって，O中で錯生成が優先 する場合（例えば $\mathrm{K}_{\mathrm{st}} \mathrm{C}_{\mathrm{Y}, 0}>10^{3}$ の場合）には次式で書 き換えられる。

$$
\begin{aligned}
& (\mathrm{F} / \mathrm{RT})\left(\triangle \phi^{0}{ }_{\mathrm{M}}-\triangle \phi^{0}{ }_{\mathrm{X}}\right) \\
& \quad=\ln \left[\mathrm{R}_{\mathrm{M}}{ }^{2} /\left[\mathrm{K}_{\mathrm{st}} \mathrm{C}_{\mathrm{Y}, 0}\left\{(\alpha-1) \mathrm{R}_{\mathrm{M}}+\alpha\right\}\right]\right]
\end{aligned}
$$

以上の考察は, $\triangle \phi^{0}{ }_{\mathrm{M}}, \Delta \phi^{0}{ }_{\mathrm{L}}, \mathrm{K}_{\mathrm{st}}, \mathrm{K}_{\mathrm{ip}}$ が既知で あれば，式 (25)〜 (28)，(37)，(38)に伡って $R_{M}$ を理 論的に予測できることを意味している。この $R_{M}$ は式 （20）によって $\mathrm{K}_{\mathrm{ex}}$ に関係付けられる，例えば，イオン 対生成および錯生成を無視できるときには，次式のよう になる。

$$
\begin{aligned}
\ln \mathrm{K}_{\text {ex }} & =\ln \left[\mathrm{R}_{\mathrm{M}}{ }^{2} /\left\{(\alpha-1) \mathrm{R}_{\mathrm{M}}+\alpha\right\}\right] \\
& =(\mathrm{F} / \mathrm{RT})\left(\triangle \phi^{0}{ }_{\mathrm{M}}-\triangle \phi^{0}{ }_{\mathrm{X}}\right)
\end{aligned}
$$

なおこのようにして予測した $\mathrm{F}_{\mathrm{M}}, \mathrm{K}_{\mathrm{ex}}$ が実験結果と 一致することも確かめられている ${ }^{5,10)}$.

本水らは，力チオンおよびアニオンの抽出性の尺度を $\mathrm{C}$ および $\mathrm{A}$ としとき， $\log \mathrm{K}_{\mathrm{ex}}$ は式 (40)で表される ことを指摘し, $\mathrm{RCOO}^{-}\left(\mathrm{R}=\mathrm{CH}_{3}\left(\mathrm{CH}_{2}\right)_{\mathrm{n}} \mathrm{CH}_{2}\right)$ を特 定のカチオンを対イオンとして CFに抽出したときの A は式 (41)のようになると報告している ${ }^{11)}$. また，同 じ $\mathrm{R}$ を持つ $\mathrm{RCOO}^{-} と \mathrm{RSO}_{3}{ }^{-}$の $\log \mathrm{K}_{\mathrm{ex}}$ の差は 1.30 であることを見いだしている.

$$
\log \mathrm{K}_{\mathrm{ex}}=\mathbf{C}+\mathbf{A}
$$

$\mathbf{A}=0.59 \mathrm{n}-9.08$

これらは，前記の考察を基に次のように解粕できる。 $\mathrm{RCOO}^{-}\left(\mathrm{R}=\mathrm{CH}_{3}\left(\mathrm{CH}_{2}\right){ }_{\mathrm{n}} \mathrm{CH}_{2}\right)$ の $\cdot \mathrm{CF}$ 間 $\triangle G_{\mathrm{tr}}{ }^{0}$ は $\mathrm{n}$ が 1 增加すると, $\triangle G_{\mathrm{s}}{ }^{0}(\mathrm{re})$ の変化を反映して $3.4 \mathrm{~kJ} \mathrm{~mol}^{-1}$ 減少する (前述)。これは $\triangle \phi^{0}{ }_{\mathrm{x}}$ が 0.035 $\mathrm{V}$ 滅少することと等価であるので (式 (1)参照)，式 (39)の関係により ( $\triangle \phi^{3}{ }_{\mathrm{M}}$ は一定), $\mathrm{n}$ が 1 増加したと き $\log \mathrm{K}_{\mathrm{ex}}$ は $(\mathrm{F} / 2.30 \mathrm{RT}) \times 0.035=16.9 \times 0.035=$ $0.59\left(25^{\circ} \mathrm{C}\right)$ 増加することを納得できる。すすなわち, 式 (41) の $0.59 \mathrm{n}$ は $\mathrm{RCOO}^{-}$の中性部分 $\mathrm{R}$ の溶媒和エネル ギーに帰することができる，一方，定数 -9.08 は電荷 部分 $\mathrm{COO}^{-}$の溶媒和エネルギーに因ると考元られるが,
数值的にはCとの関連において今後の考察を要する. 同じ R を持っ $\mathrm{RCOO}^{-}$と $\mathrm{RSO}_{3}{ }^{-}$$の G_{\mathrm{tr}}{ }^{0}$ の差は, 電 荷部分の溶媒和エネルギーを反映し， O が $\mathrm{CF}$ のとき $6.8 \mathrm{kJmol}^{-1}$ (前述) であるが, $\Delta \phi^{0}{ }_{\mathrm{x}}$ に換算すれば $0.070 \mathrm{~V}$ となる。これは， $(\mathrm{F} / 2.30 \mathrm{RT}) \times 0.070=1.2$ の $\log \mathrm{K}_{\mathrm{ex}}$ の差に相当し (式 (39) 参照), 本水らの結果と ほぼ一致する、なお，式 (40)のCは対カチオンの溶媒 和エネルギーに係わるものであろう。

\section{W/0 界面でのイオン移動反応と 電子移動 (界面酸化遇元) 反応の相関を 利用したイオンの抽出}

W/O 界面ではイオンのみでなく電子も移動する，電 子移動反応は, $W$ 中の酸化体 $\mathrm{O} 1(\mathrm{~W})$ あるいは還元体 R 1（W）が O 中の還元体 R 2（O）あるいは酸化体 O $2(\mathrm{O})$ と界面で接して行う酸化還元反応である.

$\mathrm{O} 1(\mathrm{~W})+\mathrm{R} 2(\mathrm{O}) \rightleftarrows \mathrm{R} 1(\mathrm{~W})+\mathrm{O} 2(\mathrm{O})$

$$
[\mathrm{e}(\mathrm{W}) \rightleftarrows \mathrm{e}(\mathrm{O})]
$$

この反応も，電子移動による電流 I と W/O 界面電位 差 $\triangle \mathrm{V}$ の関係曲線（液液界面電子移動ボルタモグラム） として観察され 5,12 14), 理論的解析む行われている.

Fig. 2 に電子移動ボルタモグラムの例を示す. 曲線 1 は $5 \times 10^{-4} \mathrm{M} \mathrm{Fe}(\mathrm{CN})_{6}{ }^{4-}$ を含むW $\mathrm{W} 5 \times 10^{-3} \mathrm{M}$ 7,7,8,8-テトラシアノキノジィタン (TCNQ), $10^{-2} \mathrm{M}$ $\mathrm{TCNQ}$ “を含む $\mathrm{NB}$ との界面で記録したあのである ${ }^{13)}$ ( $\mathrm{TCNQ}^{-}$; $\mathrm{TCNQ}$ アニオンラジカル). $\mathrm{TCNQ}^{-}$濃度 を $10^{-3} \mathrm{M}$ にすると曲線 2 のよになる。これらは次の 反応によって生じる.

$$
\begin{aligned}
& \mathrm{Fe}(\mathrm{CN})_{6}{ }^{4-}(\mathrm{W})+\mathrm{TCNQ}(\mathrm{O}) \\
& \rightleftarrows \mathrm{Fe}(\mathrm{CN})_{6}{ }^{3-}(\mathrm{W})+\mathrm{TCNQ}^{-}(\mathrm{O})
\end{aligned}
$$

いま，液液や液膜の界面でイオン移動之電子移動が同 時に進行するなら，これらは互いに他を促進，抑制する と考えられる. この分離化学や生体内エネルギ一変換の 視点より興味深い相関作用の定量的理解にもこれらの移 動反応のボルタモグラムは極めて有用である ${ }^{14,15)}$.

界面酸化還元反応に上って W から○に電子が移動す るとき, 電子と同当量のカチォンが同方向あるいはアニ オンが逆方向に移動しなければ，各相の電気的中性は保 てない，従って，两相が接したとき，このような条件を 満たしながらイオン招よび電子が界面を移動する。

Fig. 2 はこの関係を説明している ${ }^{15)}$. 曲線 1,2 は前述 の電子移動ボルタモグラムで, 曲線 3 あるいは 4 は $2 \times$ $10^{-4} \mathrm{M} \mathrm{K}^{+}$あるいは $\mathrm{Na}^{+}$を含むW から $10^{-3} \mathrm{M}$ バリ， マイシン (Val) を含む $\mathrm{NB} へ の \mathrm{~K}^{+}$あるいは $\mathrm{Na}^{+}$の 促進イオン移動ボル夕モグラムである。いま， $2 \times 10^{-4}$ $\mathrm{M} \mathrm{K}^{+}$扔よび $5 \times 10^{-4} \mathrm{M} \mathrm{Fe}(\mathrm{CN})_{6}^{4-}$ を含む $\mathrm{W}$ よ $10^{-3}$ $\mathrm{M} \mathrm{Val}, 5 \times 10^{-3} \mathrm{M}$ TCNQ および $10^{-2} \mathrm{M}$ TCNQ?を 含む NBが接したとすると(曲線 $1 ， 3$ 参照), 電流 $\mathrm{A}$ 
に相当する量の電子が $W$ から NBへ，それと同当量の $\mathrm{K}^{+}$が $\mathrm{W}$ から $\mathrm{NB}$ へ移動して電気的中性が保たれる。 このとき, $2 \times 10^{-4} \mathrm{M}$ 程度の $\mathrm{Na}^{+}$が W に其存していて 6, $\mathrm{Na}^{+}$の移動電位估電子移動の電位と重ならないか ら (曲線 4 参照), $\mathrm{Na}^{+}$は泣とんど移動しない, $\mathrm{TCNQ}$ を $10^{-3} \mathrm{M}$ にする (曲線 2 参照), 電子および $\mathrm{K}^{+}$の移 動量は電流 B に相当するものとなる.

イオン移動と電子移動の相関反応が平衡に達すると, 見かけ上イオンも電子も移動せず，界面を横切る電流 I は零となる.從って,イオン移動および電子移動のボル夕

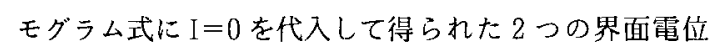
差を等しいと置けば, 平衡後の両相中のイオン濃度を理 論的に予測できる.これは実験的にも確かめられている ${ }^{15)}$.

\section{4 膜を介した一方の水相から他方の水相への イオンの電解抽出}

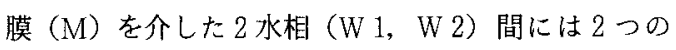
界面 (W 1/M, W 2/M) Ł3つの相 (W 1, M, W 2) が存在する. 従って, W 1-W 2 間でのイオン移動は, これらの界面および相でのイオン移動過程によって特徴 付けられる.

Fig. 3 曲線 1 は, 次式の NB 液膜（厚さ $1 \mathrm{~cm}$ ）セル

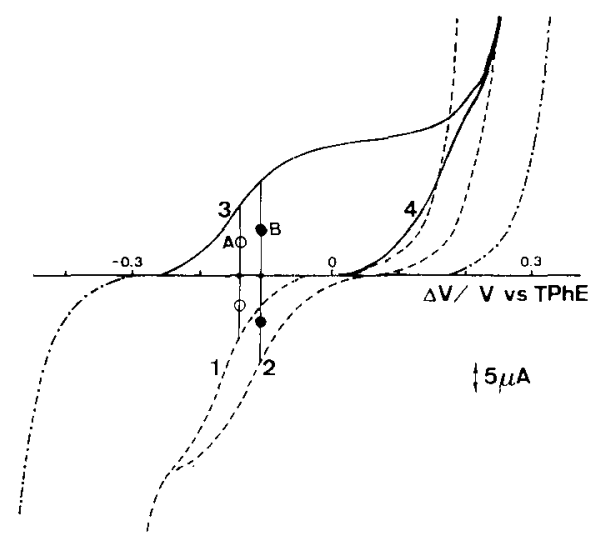

Fig. 2 Voltammograms for the transfer of electron from aqueous (W) to nitrobenzene (NB) and for the transfer of $\mathrm{K}^{+}$or $\mathrm{Na}^{+}$from $\mathrm{W}$ to $\mathrm{NB}$ facilitated by valinomycin ( $\mathrm{Val}$ ). (1), (2); $5 \times 10^{-4} \mathrm{M} \mathrm{H}_{4}\left[\mathrm{Fe}(\mathrm{CN})_{6}\right]$ in $\mathrm{W} / 5 \times 10^{-3} \mathrm{M}$ $7,7,8,8$,-tetracyanoquinodimethane (TCNQ) in $\mathrm{NB}$ in the presence of (1) $10^{-2} \mathrm{M} \mathrm{TCNQ}^{-}$or (2) $10^{-3} \mathrm{M}$ TCNQ - . (3), (4) ; (3) $10^{-4} \mathrm{M} \mathrm{K}_{2} \mathrm{SO}_{4}$ or (4) $10^{-4} \mathrm{M} \mathrm{Na}_{2} \mathrm{SO}_{4}$ in $\mathrm{W} / 10^{-3} \mathrm{M} \mathrm{Val}$ in NB. Supporting electrolytes ; $1 \mathrm{M} \mathrm{MgSO}_{4}$ in $\mathrm{W}, 0.05$ $\mathrm{M}$ crystalviolet tetraphenylborate in NB. - - ; Residual current.
によって測定した膜電流 (W 1-W 2 間イオン移動電流, $I_{W_{1-W 2}}$ ) と膜電位 (W 1-W 2 間電位差, $\triangle V_{W_{1}-W_{2}}$ ) の 関係曲線（膜透過イオン移動ボル夕モグラム， VITTM) である ${ }^{16)}$.

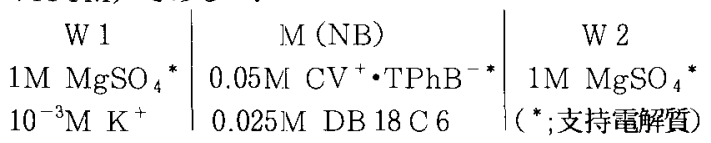

曲線 2，3は，VITTM と同時に測定したW 1/M, W 2/M界面でのイオン移動ボルタモグラムである.それ ぞれ，Mに対するW1の電位差 $\left(\triangle V_{W 1 / M}\right)$ と $\mathrm{I}_{\mathrm{W} 1-\mathrm{W} 2}$ の関係, W 2 に対する $\mathrm{M}$ の電位差 $\left(\triangle \mathrm{V}_{\mathrm{M} / \mathrm{W} 2}\right)$ と $I_{W 1-W 2}$ の関係を示す.

膜系の 2 界面を横切る電流はともに膜電流と等しいこ とを念頭に执いて，曲線 $1 ， 2 ， 3$ で任意の膜電流 $I_{0}$ を

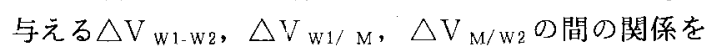
調ベると,

$\Delta V_{\mathrm{W} 1-\mathrm{W} 2}=\Delta V_{\mathrm{W} 1 / \mathrm{M}}+\Delta V_{\mathrm{M} / \mathrm{W} 2}$ が近似的に成り立つ，すなわち，本膜系のように支持電 解質が濃厚で各相の電気抵抗が小さい場合の $\triangle \mathrm{VW1-W2}$ は, W 1/M 界面での1 オン移動による $\triangle V_{\mathrm{W} 1 / \mathrm{M}}$ とW2/ $\mathrm{M}$ 界面でのイオン移動による $\triangle V_{\mathrm{M} / \mathrm{W} 2}$ の和となる。

式 (45) は， $\triangle V_{W 1-W 2}$ を印加してイオンを膜透過させ ようとするとき, $\triangle V_{W 1 / M}$ と $\triangle V_{M / W 2}$ の和は規制でき ても， $\Delta V_{W 1 / M}, \Delta V_{M} / W_{2}$ の各々を規制することはで きず，一方の界面でのイオン移動は他方の界面でのイ オン移動に影響されることを示唆する。また，一定の $\triangle V_{W_{1}-W_{2}}$ での電解によって,W 1 中のイオンをW 2 へ 抽出分離しようとするとき，電解中の W 1, M, W 2 の 組成変化に応じて $\triangle V_{W 1 / M}, \Delta V_{M / W 2}$ が相関しながら 変化することを意味し，これを認識して電解条件を選ば なければ定量的な膜分離は達成できないことを示してい る(文献 16) に詳述).

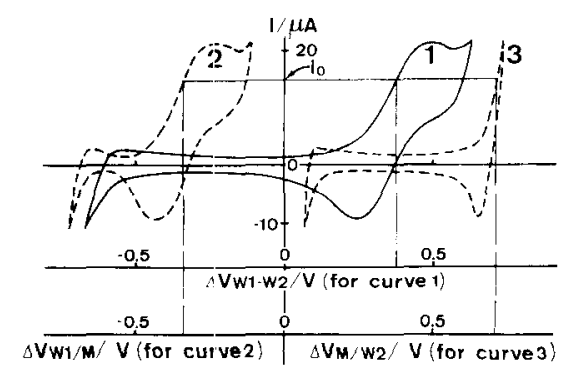

Fig. 3 Voltammograms for ion transfer through $M$ (curve 1) at the $\mathrm{W} 1 / \mathrm{M}$ interface (curve 2) and at the W2/M interface observed with the liquid membrane system of equation (44). 


\section{5 おわりに}

かって, 溶媒抽出の碩学 Henry Freiser 教授に著者 らの VITIES に関する研究を紹介したとき，教授は "Electrochemists double in solvent extraction chemists”と述べられ，早速VITIESによる溶媒抽出 反応の研究に着手された。溶媒推出化学々液液界面電気 化学とは同じ範ちゅうの学問領域に属することを直感さ れたためであろう。

本稿では，VITIESによって得られた知見を基に溶媒 抽出反応を考察し，同反応の体系的加正確な理解に電 気化学データとボルタンメトリ一的な概念, 測定法が極 めて有用であることを示した。 なお，ここでは平衡論的 側面のみを議論したが, VITJES はイオンや電子の液液 界面移動反応の速度論, 界面近傍での逐次錯生成反応, 界面構造なよ゙の研究にも本領を発揮するものであること を付記しておく（文献 1) ３），箥特集別稿を参照され たい).

最後に，液液，液膜鮆面での電荷移動反心灾の定星的理 解は，分離分析化学のみならず生体内でのイオン輸送， エネルギー変換あるいは刺激の伝達 ${ }^{5)}$ な゙゙を取り扱う生 化学の基礎にもなると考元られるので, 電気化学者と抽 出化学者の協同によって, この分野の研究がさらに進展 することを望んで止まない．

文
1) J. Koryta, Electrochim. Acta, 24, 293 (1979); 32,
419 (1987); 33, 189 (1988)

2) H.H.J. Girault and D.J. Schiffrin, Electroanalytical Chemistry (A.J. Bard Ed.), Vol.15, p.1, Marcel Dekker (1989).

3) M. Senda, T. Kakiuchi and T. Osakai, Electrochim. Acta, 36, 259 (1991).

4）木原壯林，松井正和，表面，30，367 (1992).

5) S. Kihara and K. Maeda, Prog. Surf. Sci., 47(1/2), 1 (1994).

6) S. Kihara, M. Suzuki, K. Maeda, K. Ogura and M. Matsui, J. Electroanal. Chem., 210, 147 (1986).

7) S. Kihara, M. Suzuki, M. Sugiyama and M. Matsui, J. Electroanal. Chem., 249, 109 (1981).

8) Z. Koczorowski, J. Electroanal. Chem., 127, 11 (1981).

9) T. Kakutani, Y. Nishiwaki and M. Senda, Bunseki Kagaku, 33, E 175 (1984).

10) Y. Yoshida, O. Shirai, T. Sasaki, M. Suzuki, M. Matsui and S. Kihara, Anal. Chim. Acta, 投稿中.

11) 本水昌二, 分析化学, 38, 147 (1989) 亡引用文献.

12) Z. Samec, V. Marecek and J. Weber, J. Electroanal. Chem., 96, 245 (1979).

13) S. Kihara, M. Suzuki, K. Maeda, K. Ogura, M. Matsui and Z. Yoshida, J. Electroanal. Chem., 271, 107 (1989).

14) V.J. Cunnane, D.J. Schiffrin, C. Beltran, G. Geblewicz and T. Solomon, J. Electroanal. Chem., 247, 203 (1988).

15) K. Maeda, S. Kihara, M. Suzuki and M. Matsui, J. Electroanal. Chem., 303, 171 (1991).

16) O. Shirai, S. Kihara, Y. Yoshida and M. Matsui, $J$. Electroanal. Chem., 印刷中.

\section{马 液液界面を用いる電気分析化学の進歩}

千田貢

\section{1 はじめに}

互いに混じり合わない二つの電解質溶液間の界面（以 下，油水界面上呼ぶ）に扔けるイオン及び電子の移動反 応の電気化学, 電気分析化学的研究の最近の進歩の一端 を紹介したい，著者等の興味にかたよったもの，また不 勉強で文献の見落しなよ゙，御寛容を抢願いしたい。

1990 年頃までの進歩については，総説 ${ }^{1)}$ また総合論 文 ${ }^{2 \sim 5)}$ を参考にされたい.

\section{1 油水界面イオン促進移動}

\section{2 油水界面イオン移動反応}

油相中に存在するイオノフォアーLが水相中のイオン

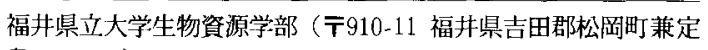
島 4-1-1)
$\mathrm{M}$ と親油性の錯体 ML 等を形成することによるイオン $\mathrm{M}$ の油水界面促進移動反応の研究に関しては，イオン センサーの基礎的研究の見地加らむ, 従来から多くの研 究があるが，ビちらかというとLが著しく親油性でそ の水相への分配が事害上無視出来る上みなせる系に関す る屯のが多かった．松田等 ${ }^{6)}$ は L の油水相間分配係数 $\mathrm{K}_{\mathrm{D}}$ が任意の場合について，そのイオン促進移動反応の ポーラログラフ可逆波（錯体の形成，解離，また L, M を含めそれらの界面移動，分配の速度が充分速く，平衡 関係が成立しているとみなせる場合）の理論式を導き， $\mathrm{Cs}^{+}, \mathrm{Na}^{+}, \mathrm{Ba}^{2+}, \mathrm{H}_{3} \mathrm{O}^{+}$イオンのイオノフォアー $\mathrm{DB}$ $16 \mathrm{C} 6\left(\mathrm{~K}_{\mathrm{D}}=2.3 \times 10^{4}\right)$ 及び $16 \mathrm{C} 6\left(\mathrm{~K}_{\mathrm{D}}=0.1\right)$ によ るニトロベンゼン $(\mathrm{NB}) /$ 水 $(\mathrm{W})$ 界面促進移動反応 による液滴電極ポーラログラフ波の詳細な解析を行い, 